\title{
EFFECT OF INOCULATION ON THE FORMATION OF CHUNKY GRAPHITE IN DUCTILE-IRON CASTINGS
}

\author{
VPLIV MODIFIKACIJE NA NASTANEK GRUDASTEGA GRAFITA \\ V ULITKIH IZ GNETLJIVEGA ŽELEZA
}

\author{
Ivana Mihalic Pokopec ${ }^{1}$, Primož Mrvar², Branko Bauer ${ }^{1}$ \\ ${ }^{1}$ University of Zagreb, Faculty of Mechanical Engineering and Naval Architecture, Ivana Lucica 5, 10002 Zagreb, Croatia \\ ${ }^{2}$ University of Ljubljana, Faculty of Natural Science and Engineering, Lepi pot 11, 1000 Ljubljana, Slovenia \\ branko.bauer@fsb.hr
}

Prejem rokopisa - received: 2015-12-23; sprejem za objavo - accepted for publication: 2016-02-22

doi:10.17222/mit.2015.355

\begin{abstract}
Chunky graphite is one of the most deleterious graphite degenerations in thick-walled ductile-iron castings. This defect normally appears in the thermal center of a casting and dramatically decreases the mechanical properties. Chunky-graphite formation is primarily caused by a reduction in the cooling rate and melt composition. An addition of subversive elements (Bi, $\mathrm{Sb}, \mathrm{Pb}, \mathrm{Sn}, \ldots$ ) associated with a small amount of $\mathrm{Ce}$ is known to be beneficial to avoid chunky graphite. In this study, the effects of $\mathrm{Bi}$ and $\mathrm{Ce}$ additions at different cooling rates on the graphite morphology and mechanical properties of ductile-cast iron EN-GJS-400-18-LT were investigated. Y-blocks with wall thicknesses of $25 \mathrm{~mm}$ and $75 \mathrm{~mm}$ and cylindrical blocks with a diameter of $200 \mathrm{~mm}$ and a height of $300 \mathrm{~mm}$ were cast. The presence of chunky graphite in the thermal center of the cylindrical blocks and a decrease in the mechanical properties were revealed, regardless of the presence of $\mathrm{Bi}$.

Keywords: chunky graphite, cooling rate, graphite morphology, thick-walled ductile-iron castings
\end{abstract}

Grudast grafit je ena od najbolj škodljivih degeneracij grafita v debelostenskih ulitkih iz gnetljivega železa. Ta napaka se običajno pojavi v toplotnem središču ulitka in močno zmanjša mehanske lastnosti. Nastanek grudastega grafita je posledica zmanjšanja hitrosti ohlajanja in sestave taline. Dodatek škodljivih elementov v sledovih (Bi, $\mathrm{Sb}, \mathrm{Pb}, \mathrm{Sn}, . ..) \mathrm{v}$ povezavi z majhnim dodatkom Ce je poznan kot ugoden za preprečitev nastanka grudastega grafita. V tej študiji je bil proučevan vpliv dodatka $\mathrm{Bi}$ in $\mathrm{Ce}$ pri različnih hitrostih ohlajanja na morfologijo grafita in mehanske lastnosti gnetljivega litega železa EN-GJS-400-18-LT. Uliti so bili Y-kosi z debelino stene $25 \mathrm{~mm}$ in $75 \mathrm{~mm}$ ter cilindrični kosi s premerom $200 \mathrm{~mm}$ in visoki $300 \mathrm{~mm}$. Odkriti sta bili prisotnost grudastega grafita v toplotnem središču cilindričnih kosov ter zmanjšanje mehanskih lastnosti, neodvisno od prisotnosti Bi.

Ključne besede: grudast grafit, hitrost ohlajanja, morfologija grafita, debelostenski ulitki iz gnetljivega železa

\section{INTRODUCTION}

Chunky graphite, $\mathrm{CHG}$, is one of the most deleterious graphite degenerations in thick-walled ductile-iron castings. CHG normally appears in the thermal center of large castings, and decreases the mechanical properties, in particular the tensile and fatigue strength and elongation. Local, cell-type accumulations of compact graphite forms are characteristic for $\mathrm{CHG} .{ }^{1}$ On the macro-scale, it is optically visible on cut or machined surfaces as a black spot. Microscopic observation shows that $\mathrm{CHG}$ consists of large cells of highly branched and interconnected graphite strings. A graphite nodule can usually be observed at the end of these strings. CHG grows along the c-axis with a spiral growth mechanism. Although the mechanism of growth is the same as with spheroidal graphite, its driving forces are different. ${ }^{2}$

A great number of studies have been conducted to describe the CHG formation, but a clear understanding of its appearance and a safe mastering of the metal preparation to avoid CHG are not yet available.

The main causes of a CHG formation are a slower cooling rate and the melt composition. ${ }^{3,4}$ With slower cooling rates and increasing section thicknesses, the size of the spherulites increases and their count per unit of area decreases. In such zones, CHG frequently develops as a result of graphite degeneration. ${ }^{1,5}$ A high carbon equivalent, approx. $>4.1 \%$ of mass fractions, and increasing contents of the elements such as $\mathrm{Ni}, \mathrm{Si}, \mathrm{Cu}, \mathrm{Ce}$, $\mathrm{Ca}, \mathrm{Al}, \mathrm{P}, \mathrm{Mg}$ promote the formation of $\mathrm{CHG} .{ }^{1,2,6,7}$

The CHG formation is also affected by the presence of low-level elements in the melt. It has been well documented that the presence of either subversive elements, such as $\mathrm{Pb}, \mathrm{Bi}, \mathrm{Sb}$ and $\mathrm{As}$, or excessive $\mathrm{RE}$ amounts cause the degeneration of graphite spheriods, i.e., the $\mathrm{CHG}$ formation. However, the co-existence of subversive elements and RE in appropriate ratios will result in the retention of spheroidal graphite. ${ }^{8,9}$

It was found that small amounts of bismuth added to the melt promote the formation of spheroidal graphite. However, when its content exceeds the critical value, Bi is known as a detrimental element, which can cause degeneration of a good nodular graphite structure. This effect was attributed to the interaction between $\mathrm{Bi}$ and $\mathrm{Mg}$, which blocks the spheroidization effect of $\mathrm{Mg}$ to a certain extent. This negative effect of $\mathrm{Bi}$ is mostly 
neutralized with RE additions, especially Ce. The interaction effect between $\mathrm{RE}$ and $\mathrm{Bi}$ is achieved with the formation of various types of intermetallic compounds, e.g., $\mathrm{Bi}_{3} \mathrm{Ce}_{4}, \mathrm{BiCe}_{3}$, etc. Intermetallic compounds delete the effect of subversive elements, and also serve as nuclei for the graphite formation. ${ }^{5,9,10}$ According to reference ${ }^{11}$, adding $0.002-0.006 \%$ of mass fraction of $\mathrm{Bi}$ with a certain amount of $\mathrm{Ce}$, increases the nodule count and prevents the $\mathrm{CHG}$ formation in thick sections. But, when the amount of RE exceeds the value required for neutralization of the subversive elements, CHG may form. ${ }^{5}$

In reference ${ }^{10}$, it was found that a $\mathrm{Ce} / \mathrm{Bi}$ ratio of $0.8-1.1$ was sufficient to achieve a complete neutralization of the castings with a relatively long solidification time (e.g., $3200 \mathrm{~s}$ ), while $\mathrm{Ce} / \mathrm{Bi}$ ratios in excess of 1.1 were required for the castings with very short solidification times (e.g., $100 \mathrm{~s}$ ).

P. Ferro et al. ${ }^{5}$ studied the effects of an inoculant sequence and inoculant chemical composition on a casting heavy-section microstructure. An in-stream inoculation with an inoculant containing $\mathrm{RE}$ and $\mathrm{Bi}$ was found to drastically reduce the formation of $\mathrm{CHG}$. This result was attributed to the major fading resistance of such an inoculant compared to the standard ones. They found that $\mathrm{Bi}$ is suppressing or reducing the $\mathrm{CHG}$ formation by reducing the undercooling, which is considered the main reason for the $\mathrm{CHG}$ formation. In this case, $\mathrm{Bi}$ behaves in a similar way like $\mathrm{Sb}$, whose effect was confirmed by P. Larrañaga et al. ${ }^{12}$ Bismuth also has the function to remove the oxygen absorbed at the interface between graphite and liquid iron, thus reducing the oxygen absorption and preventing the formation of $\mathrm{CHG}^{5}$

Although it is known that the correlation between the ratio of RE/subversive elements and the appearance of chunky graphite in thick-walled ductile-iron castings exists, this area is still not fully investigated. More work is needed to provide a correct balancing of the RE/Bi ratio that would prevent the formation of chunky graphite.

In the present work, the solidification behavior of large ductile-iron blocks with or without an addition of $\mathrm{Bi}$ and the same amount of $\mathrm{Ce}$ are compared by means of a microstructure observation and measuring of mechanical properties. $\mathrm{Bi}$ and $\mathrm{Ce}$ were supplied from different inoculants.

\section{EXPERIMENTAL PART}

The test castings used in this study were $\mathrm{Y}$ blocks, $25 \mathrm{~mm}$ and $75 \mathrm{~mm}$ in size and cylindrical blocks with a diameter of $200 \mathrm{~mm}$ and a height of $300 \mathrm{~mm}$, Figure 1, to enable the investigation of the influence of different solidification times on the chunky graphite formation. The thermal modulus, i.e., the relation between the volume and the cooling surface area (V/A) of a cylinder was $3.75 \mathrm{~cm}$
Two moulds (M1, M2), with the same test castings, were produced from sodium silicate bonded sand.

With the aim to limit the number of the parameters, all the samples were cast using the same melt. The melt was produced in a $5.6 \mathrm{t}$ capacity medium-frequency induction furnace. The charge material consisted of grey pig iron $\left(\right.$ Sorelmetal ${ }^{\circledR}$ ), steel scrap and returns as listed in Table 1. In order to increase the carbon and silicon content and the nucleation ability of the melt, $\operatorname{SiC}(\sim 92 \%$ of the mass fractions of $\mathrm{SiC}$ ) was added into the furnace with the metallic charge. Once the melting was finished, the chemical composition of the metal was adjusted according to the carbon and silicon evaluation obtained with a thermal analysis and spectrometric analysis carried out on the coupon for the other elements.

Table 1: Charge materials used for melting

Tabela 1: Vložki, uporabljeni za pretaljevanje

\begin{tabular}{|c|c|c|c|c|}
\hline $\begin{array}{c}\text { total mass } \\
(\mathrm{kg})\end{array}$ & $\begin{array}{c}\text { pig iron } \\
(\mathrm{kg})\end{array}$ & $\begin{array}{c}\text { steel scrap } \\
(\mathrm{kg})\end{array}$ & $\begin{array}{c}\text { returns } \\
(\mathrm{kg})\end{array}$ & $\begin{array}{c}\mathrm{SiC} \\
(\mathrm{kg})\end{array}$ \\
\hline 5600 & 4026 & 448 & 1120 & 6 \\
\hline & $72(w / \%)$ & $8(w / \%)$ & $20(w / \%)$ & $0.1(w / \%)$ \\
\hline
\end{tabular}

For both moulds, the spheroidising treatment was carried out in a dedicated ladle with a capacity of $200 \mathrm{~kg}$ by adding $\sim 2 \%$ of the mass fractions of the FeSiMg alloy (44-48\% of the mass fraction of $\mathrm{Si}, 3.5-3.8 \%$ of mass fraction of $\mathrm{Mg}, 0.9-1.1 \%$ of the mass fraction of $\mathrm{Ca}, 0.5-1.2 \%$ of the mass fraction of $\mathrm{Al}, 0.6-0.8 \%$ of the mass fractions of RE, and Fe bal.) using the sandwich method at $\sim 1480{ }^{\circ} \mathrm{C}$. The FeSiMg alloy was positioned at the bottom of the casting ladle and then covered with steel scrap before pouring the iron from the furnace. $0.7 \%$ of the mass fraction of $\mathrm{Ni}$ was also added to the casting ladle. The source of $\mathrm{Ni}$ is $99.9 \%$ of the mass fractions of the $\mathrm{Ni}$ pure metal. In this type of industrial alloy, it is not possible to sustain the requested $95 \%$ of the mass fraction of the ferritic matrix in the as-cast state, so it has to be heat treated. $\mathrm{Ni}$ is added to assure the requested tensile strength (above $400 \mathrm{~N} / \mathrm{mm}^{2}$ ) and to improve the low-temperature ductility after the heat treatment of this alloy.

Simultaneously with the spheroidising treatment, the first inoculation (preconditioning) was carried out by adding $0.2 \%$ of the mass fraction of commercial inoculant I1. After the treatment, slag was removed from the melt surface and the melt was poured into the mould. The holding time was $\sim 3$ min. The second inoculation (in-stream) during the pouring of the mould was performed by adding $0.2 \%$ of the mass fraction of inoculant $\mathrm{I} 2$, containing $\mathrm{Ce}$, at $\sim 1380{ }^{\circ} \mathrm{C}$. The $\mathrm{Mg}$ recovery was about $75 \%$.

In order to investigate the influence of the Bi-containing inoculant in the second mould, inoculation was additionally performed by adding commercial inoculant I3, in the form of a block fixed with the foundry adhesive to the bottom of the downsprue, as indicated in Figure 1. 


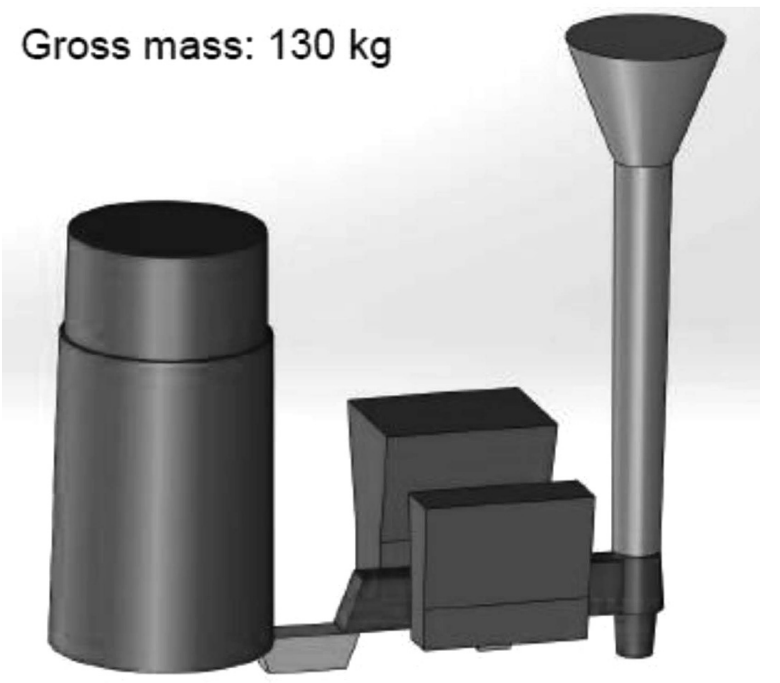

Figure 1: Pattern used in the experiment Slika 1: Vzorec, uporabljen pri preizkusu

The chemical composition of the used inoculants is reported in Table 2 . The pouring temperature for both moulds was $1380{ }^{\circ} \mathrm{C}$ and the pouring time was $27 \mathrm{~s}$.

Just before pouring the melt to the mould, the chilled coupon was analysed with an optical emission spectrometer (ARL 3460). The C and Si contents were determined from the results of the thermal analysis using the ATAS $^{\circledR}$ system. The chemical compositions are listed in Table 3.

Each cylindrical block was afterwards sectioned along the vertical symmetry plane to evaluate the zone affected by CHG. As illustrated in Figure 2, the zone affected by $\mathrm{CHG}$ was easily located as the darker zone in the thermal center of the casting. Zones 1 and 2 were from the $\mathrm{CHG}$ area and zone 3 was from the border of the $\mathrm{CHG}$ area. Also, the samples obtained from these zones were prepared for the metallographic analysis; samples S1, S2 and S3 as shown in Figure 2. The metallographic analysis was done with an optical microscope (Olympus GX 51), equipped with a system for automatic image processing (Analysis ${ }^{\circledR}$ Materials Research Lab). All the metallographic parameters such

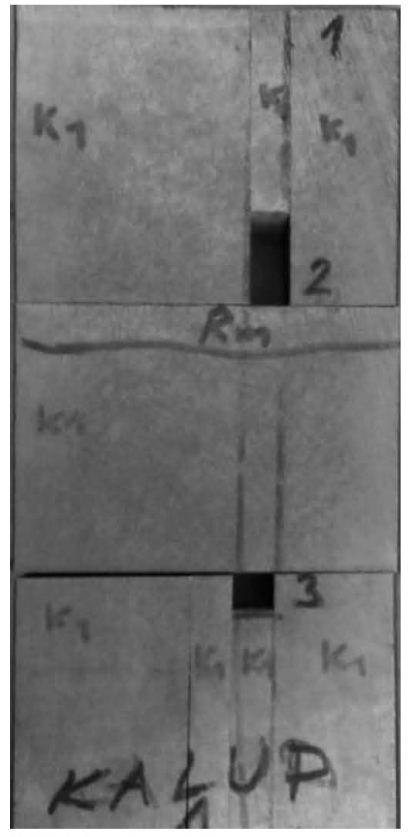

M1 block

Figure 2: Central sections of cast cylindrical blocks M1 and M2 (zones 1, 2 and 3)

Slika 2: Sredinski del cilindričnih kosov M1 in M2 (področja 1, 2 in 3)

as nodularity, nodule count, nodule size, area fraction of graphite, graphite particle size class distribution, graphite shape classification and ferrite/pearlite ratio were evaluated according to the Standard EN-ISO 945-1 2010. Finally, tensile-test bars were machined out from the core of each cylindrical block as indicated in Figure 2.

Y blocks of $25 \mathrm{~mm}$ and $75 \mathrm{~mm}$ were also machined to obtain tensile-test bars. The samples for the metallographic analysis of the Y blocks were collected from the heads of the tensile-test bars.

The microstructure in the vicinity of the fracture surface of the tensile-test bars was investigated under an optical microscope.

The samples for the metallographic analysis were prepared with the standard methods of grinding, polishing and etching in $5 \%$ nital. The microstructures

Table 2: Chemical compositions of inoculants

Tabela 2: Kemijska sestava modifikatorjev

\begin{tabular}{|c|c|c|c|c|c|c|c|c|c|c|c|}
\hline \multirow{2}{*}{ Inoculant } & \multicolumn{11}{|c|}{ Chemical composition, $(w / \%)$} \\
\hline & $\mathrm{Si}$ & $\mathrm{Mg}$ & $\mathrm{Ca}$ & $\mathrm{Al}$ & $\mathrm{Ce}$ & $\mathrm{Ba}$ & $\mathrm{RE}$ & $\mathrm{Bi}$ & $\mathrm{S}$ & $\mathrm{O}$ & $\mathrm{Fe}$ \\
\hline I1 & $64-70$ & - & $1.0-2.0$ & $0.8-1.5$ & - & $2.0-3.0$ & - & - & - & - & bal. \\
\hline $\mathrm{I} 2$ & $70-76$ & - & $0.75-1.25$ & $0.75-1.25$ & $1.5-2.0$ & - & - & - & $(<1 \%)$ & $(<1 \%)$ & bal. \\
\hline $\mathrm{I} 3$ & 71.33 & & \begin{tabular}{|l|}
0.79 \\
\end{tabular} & 3.96 & & & & 1.20 & & & \\
\hline
\end{tabular}

Table 3: Chemical compositions of the melts, $(w / \%)$

Tabela 3: Kemijska sestava talin, (w/\%)

\begin{tabular}{|c|c|c|c|c|c|c|c|}
\hline & $\mathrm{C}$ & $\mathrm{Si}$ & $\mathrm{Mn}$ & $\mathrm{P}$ & $\mathrm{S}$ & $\mathrm{Mg}$ & $\mathrm{Ni}$ \\
\hline $\mathrm{M} 1$ & 3.68 & 1.65 & 0.13 & 0.034 & 0.01 & 0.049 \\
\hline M2 & 3.67 & 1.62 & 0.13 & 0.032 & 0.011 & 0.043 & 0.761 \\
\hline
\end{tabular}


I. MIHALIC POKOPEC et al.: EFFECT OF INOCULATION ON THE FORMATION OF CHUNKY GRAPHITE ...

were analysed according to the Standard EN ISO 945-1:2008.

Tensile tests were carried out on a tensile-testing machine (Fritz Heckert ZD-20) at room temperature on five samples taken from the Y blocks and two samples taken from the cylindrical blocks. The yield strength, tensile strength and elongation were determinated according to the Standard EN 1563.

\section{RESULTS}

\subsection{Macro- and microstructures}

Usually $\mathrm{CHG}$ is easily detected after sectioning a casting. The presence of $\mathrm{CHG}$ is visible as a localized darkening of the surface, often revealed without any need of chemical etching. In Figure 2, the CHG macrostructures of the cross-sections of the cylindrical blocks are clearly visible. $\mathrm{CHG}$ appeared in the thermal centers due to the slowest cooling rates, in both blocks, with and without $\mathrm{Bi}$. The solidification time in the centre was $5140 \mathrm{~s}$, determined from the results of the simulation in the ProCAST ${ }^{\circledR}$ software. Evident differences in the proportion of the areas affected by CHG in these two cast blocks were observed, as shown in Figures 2 and $\mathbf{3}$.

The diameter of the area affected by CHG at the top of zone 1 for M1 was $129 \mathrm{~mm}$, and $78 \mathrm{~mm}$ for M2, Figure 3. The area affected by $\mathrm{CHG}$ appeared in an ellipsoid shape in the cross-section along the vertical symmetry plane, for both blocks. The CHG zone for M1 starts $58 \mathrm{~mm}$ from the bottom of the block, and $87 \mathrm{~mm}$ for M2, as can be seen in Figure 2.

An addition of $\mathrm{Bi}$ caused a significant reduction of the $\mathrm{CHG}$-affected zone, at the lower cooling rates in the centre of a block.

The microscopic observation showed that CHG occurred locally, having typical cell-type structures, Figure 4. These cells were relatively large, with the apparent diameter in the range of $0.5-1.5 \mathrm{~mm}$, with a sharp transition between the non-affected and the affected zones, Figures $\mathbf{4}$ and 5. Inside the CHG area, zones with spherical graphite were found. Distribution of CHG is generally not uniform within the affected zone.
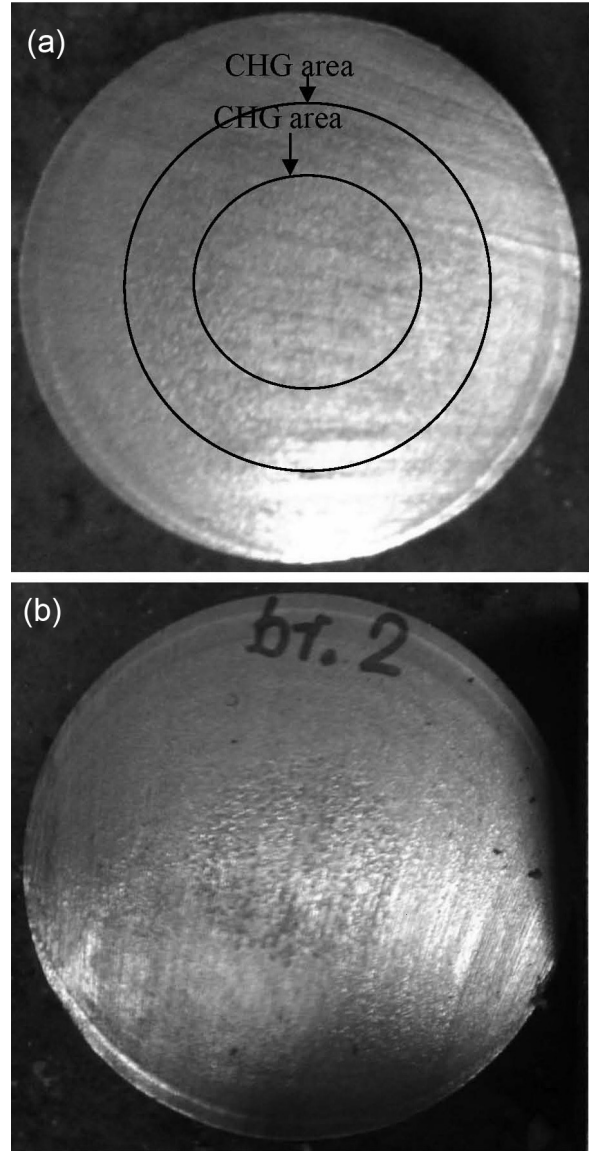

Figure 3: Cross-sections of cast blocks at the top of zone 1: a) M1 without $\mathrm{Bi}$, b) $\mathrm{M} 2$ with $\mathrm{Bi}$

Slika 3: Prerez ulitega kosa na vrhu področja 1: a) M1 brez Bi, b) $\mathrm{M} 2 \mathrm{z} \mathrm{Bi}$

The samples with a Bi addition showed a pronounced eutectic growth in zones 1 and 3, while in the samples without a $\mathrm{Bi}$ addition, it was more difficult to distinguish specific cells in zones 1 and 2, Figure 4. The nodules around the CHG area in zones 1 and 2 showed a regular shape, while in zone 3 more degenerated nodules were found.

As can be seen from Table 4, after long solidification times, from $3670 \mathrm{~s}$ to $5140 \mathrm{~s}$, a significant graphite deterioration occurred with the graphite nodularity in the vicinity of $50 \%$, and a very low nodule count, below 50

Table 4: Graphite-microstructure data for cylindrical blocks in CHG area according to EN-ISO 945-1

Tabela 4: Podatki o mikrostrukturi grafita v cilindričnih kosih v področju CHG, skladno z EN-ISO 945-1

\begin{tabular}{|c|c|c|c|c|c|c|c|c|c|c|c|c|}
\hline \multirow[b]{2}{*}{ Mould } & \multirow[b]{2}{*}{$\begin{array}{c}\text { Zone } \\
\text { (Figure } \\
\text { 2) }\end{array}$} & \multirow[b]{2}{*}{ Shape } & \multirow[b]{2}{*}{ Size } & \multirow[b]{2}{*}{$\begin{array}{c}\text { Nodula- } \\
\text { rity } \\
(\%)\end{array}$} & \multirow[b]{2}{*}{$\begin{array}{c}\text { Nodule } \\
\text { count } \\
\left(\mathrm{mm}^{-2}\right)\end{array}$} & \multirow{2}{*}{$\begin{array}{c}\text { Area } \\
\text { frac. of } \\
\text { graphite } \\
(\%)\end{array}$} & \multicolumn{6}{|c|}{ Size distribution } \\
\hline & & & & & & & $\begin{array}{c}3 \\
(\max . \\
500 \mu \mathrm{m})\end{array}$ & $\begin{array}{c}4 \\
(\max . \\
250 \mu \mathrm{m})\end{array}$ & $\begin{array}{c}5 \\
(\max . \\
120 \mu \mathrm{m})\end{array}$ & $\begin{array}{c}6 \\
(\max . \\
60 \mu \mathrm{m})\end{array}$ & $\begin{array}{c}7 \\
(\max . \\
30 \mu \mathrm{m})\end{array}$ & $\begin{array}{c}8 \\
(\max . \\
15 \mu \mathrm{m})\end{array}$ \\
\hline \multirow{3}{*}{ M1 } & 1 & V,III(35 \%) & 6 & 47 & 65 & 10.7 & 0 & 3 & 107 & 426 & 789 & 1284 \\
\hline & 2 & V,II $(35 \%)$ & 5 & 48 & 38 & 10.8 & 2 & 11 & 87 & 330 & 473 & 741 \\
\hline & 3 & IV & 6 & 51 & 47 & 11.1 & 1 & 8 & 67 & 392 & 753 & 1287 \\
\hline \multirow{3}{*}{ M2 } & 1 & V,II (40\%) & 6 & 45 & 25 & 10.4 & 0 & 5 & 105 & 472 & 729 & 807 \\
\hline & 2 & & 6 & 49 & 42 & 8.9 & 0 & 12 & 99 & 365 & 463 & 396 \\
\hline & 3 & V,II $(45 \%)$ & 6 & 40 & 43 & 10.3 & 0 & 10 & 135 & 459 & 788 & 694 \\
\hline
\end{tabular}


Ml without $\mathrm{Bi}$

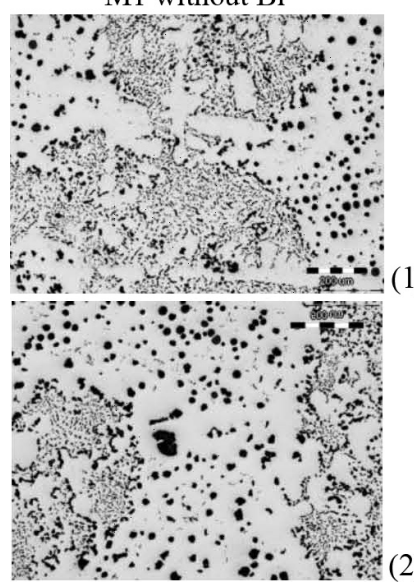

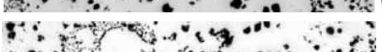

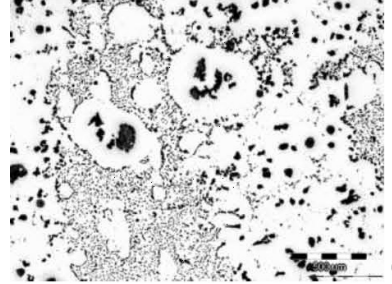

Figure 4: Microstructures from zones 1,2, 3 from blocks M1 and M2 Slika 4: Mikrostrukture iz različnih področij 1, 2, 3, iz kosov M1 in M2
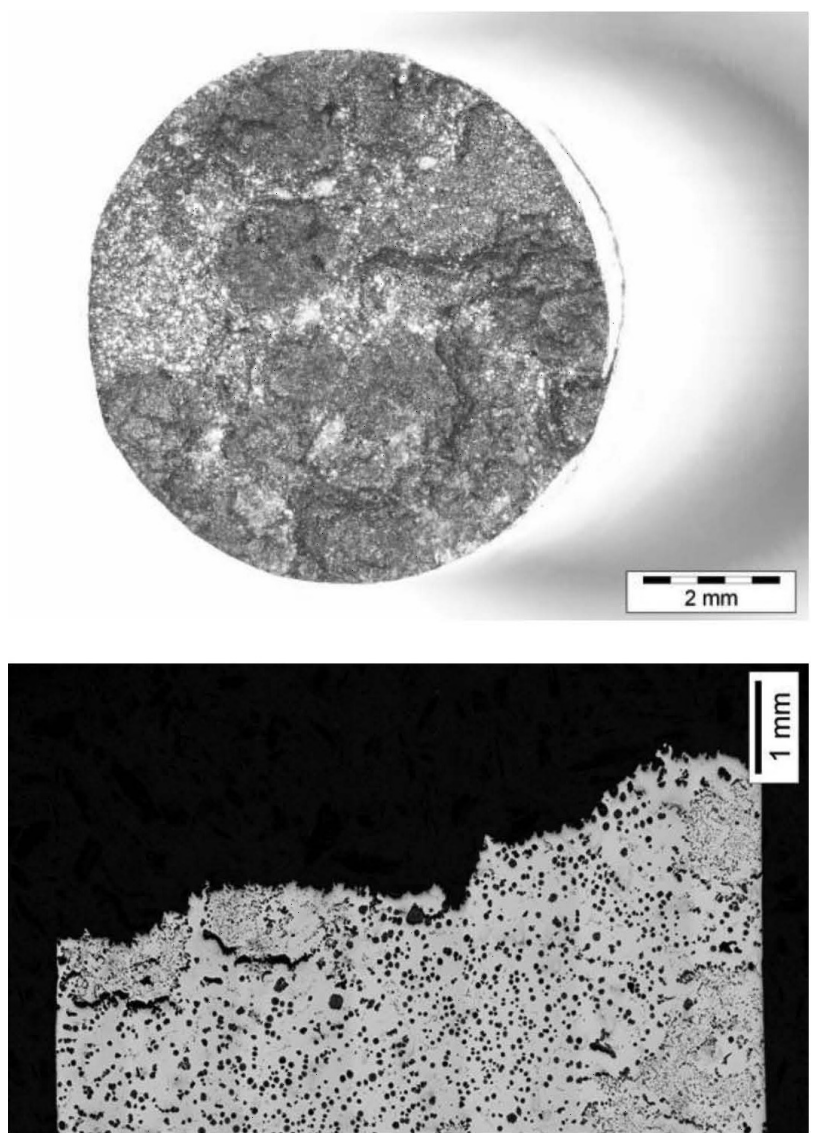

Figure 5: Fracture surface of a test bar (M1-2)

Slika 5: Prelom preizkusne palice (M1-2) nodules $/ \mathrm{mm}^{2}$ (except in zone 1 of $\mathrm{M} 1$ ). The obtained nodule count was substantially below the recommended minimum nodule count for heavy-section castings, which is more than 60 nodules $/ \mathrm{mm}^{2}$. The results were slightly inferior for the samples with the Bi addition. The results of the nodule count cannot be related with the solidification time. The lowest nodule count was observed for cylindrical block M2. With the decrease in the nodule count for the cylinders, the size of the nodules increased, Figure 4. Also, the $\mathrm{Bi}$ addition reduced the amount of ferrite, from approx. 90 to $80 \%$, Table 5 .

Table 5: Ferrite/pearlite ratio of cylindrical blocks in $\mathrm{CHG}$ area according to EN-ISO 945-1

Tabela 5: Razmerje ferit/perlit v cilindričnih kosih v področju CHG, skladno z EN-ISO 945-1

\begin{tabular}{|c|c|c|c|}
\hline \multirow{2}{*}{ Mould } & $\begin{array}{c}\text { Zone } \\
\text { (Figure 2) }\end{array}$ & $\begin{array}{c}\text { Ferrite area } \\
\%\end{array}$ & $\begin{array}{c}\text { Pearlite area } \\
\%\end{array}$ \\
\hline \multirow{3}{*}{ M1 } & 1 & 91.4 & 8.6 \\
\cline { 2 - 4 } & 2 & 91.8 & 8.2 \\
\cline { 2 - 4 } & 3 & 90.6 & 9.4 \\
\hline \multirow{3}{*}{ M2 } & 1 & 85.3 & 14.7 \\
\cline { 2 - 4 } & 2 & 81.4 & 18.6 \\
\cline { 2 - 4 } & 3 & 79.8 & 20.2 \\
\hline
\end{tabular}
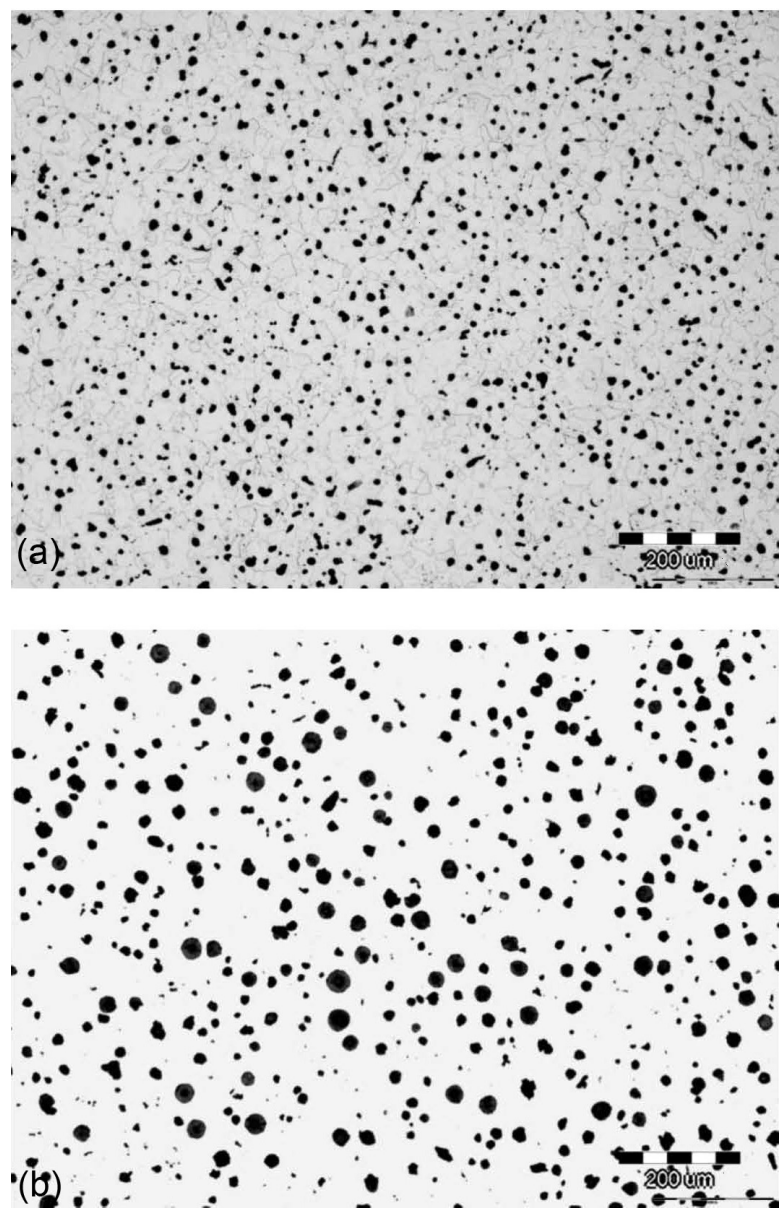

Figure 6: Microstructures of Y-blocks, $25 \mathrm{~mm}$ : a) M1 without Bi, b) M2 with $\mathrm{Bi}$

Slika 6: Mikrostrukturi Y-kosa, 25 mm: a) M1 brez Bi, b) M2 z Bi 
In the Y blocks of $25 \mathrm{~mm}$ and $75 \mathrm{~mm}, \mathrm{CHG}$ did not appear, Figure 6. The nodule count of the Y blocks was in a range from 74 to 405 nodules $/ \mathrm{mm}^{2}$. The nodularity was from $60 \%$ to $73 \%$. The bismuth addition negatively affected the microstructure regarding the nodule count, while the nodularity was positively affected.

\subsection{Tensile test}

Table 6 gives the tensile-test results for the $\mathrm{CHG}$ area in the cylindrical blocks. The samples containing $\mathrm{CHG}$ were characterized by a significant reduction in the elongation and tensile strength compared to the CHG-free samples from the $\mathrm{Y}$ blocks. The samples from the $\mathrm{Y}$ blocks showed elongation values in the vicinity of $18 \%$, while the samples containing $\mathrm{CHG}$ achieved elongation values in a range of 3.5-7.5\%. The tensile strength values for the CHG area were reduced by 20-25\%, while the yield strength was reduced by $10 \%$. Hardness was hardly affected at all.

Table 6: Mechanical properties in the CHG area

Tabela 6: Mehanske lastnosti v področju $\mathrm{CHG}$

\begin{tabular}{|c|c|c|c|c|c|}
\hline \multirow{2}{*}{ Mould } & Specimen & $\begin{array}{c}R_{\mathrm{m}} \\
\mathrm{N} / \mathrm{mm}^{2}\end{array}$ & $\begin{array}{c}R_{\mathrm{p} 0,2} \\
\mathrm{~N} / \mathrm{mm}^{2}\end{array}$ & $\begin{array}{c}\mathrm{A}_{5} \\
\%\end{array}$ & $\mathrm{HB}$ \\
\hline \multirow{2}{*}{ M1 } & 1 & 323 & 269 & 4.2 & 140 \\
\cline { 2 - 6 } & 2 & 317 & 269 & 3.5 & - \\
\hline \multirow{2}{*}{ M2 } & 1 & 345 & 249 & 7.5 & 123 \\
\cline { 2 - 6 } & 2 & 331 & 259 & 5.5 & - \\
\hline
\end{tabular}

The effect of the $\mathrm{Bi}$ addition on the mechanical properties can be seen. In the $\mathrm{CHG}$ area, the $\mathrm{Bi}$ addition resulted in better elongation and tensile-strength properties, while the yield strength and hardness were slightly reduced, Table 6 . In the Y blocks, the Bi addition positively influenced the elongation properties, while the strength properties were reduced.

Visual testing of the fracture surfaces of the tensiletest bars pointed out local dark areas of various sizes. The macroscopic observation of CHG corresponded very well with the microscopic observations, Figure 5. On the fracture surface, eutectic cells of chunky graphite surrounded with normal spheroidal graphite were detected.

\section{DISCUSSION}

High concentrations of $\mathrm{Ce}, \mathrm{Ca}, \mathrm{Si}$ and $\mathrm{Ni}$ are the usual reasons of the $\mathrm{CHG}$ formation. Excessive $\mathrm{Ce}$, in the absence of subversive elements in heavy-section ductile iron will almost always cause a CHG formation. In thin-section castings, the risk of a CHG formation is minimum due to short solidification times.

Most MgFeSi alloys contain some level of RE, especially $\mathrm{Ce}$, to promote a high nodule count, improve nodularity and counteract the effects of anti-nodularising elements. This is usually good for thin-section parts, but it is a problem for the sections thicker than $50 \mathrm{~mm}$. There is a unified opinion found in the literature that an addition of $\mathrm{Bi}$ (up to about $0.003 \%$ of mass fraction) can prevent the formation of degenerated graphite in thicksection castings. ${ }^{14}$ To eliminate the detrimental effect of $\mathrm{RE}$, the most important task to do is to achieve the right balance between the presence of RE and the subversive elements. ${ }^{1,7}$ Note also that the amount of $\mathrm{Bi}$ required to counteract the detrimental effect of RE (Ce) is casting section-size dependent.

In this study the $\mathrm{Bi}$ addition did not totally suppress the $\mathrm{CHG}$ formation, but the added amount reduced the area affected with $\mathrm{CHG}$. The amount of $\mathrm{Bi}$ was too low and the presumption is that the right balance between $\mathrm{Ce}$ and $\mathrm{Bi}$ would prevent the formation of $\mathrm{CHG}$.

The microstructure analysis of the $\mathrm{CHG}$ area in the cylindrical blocks showed similar results with and without a $\mathrm{Bi}$ addition. The present results indicate that the addition of $\mathrm{Bi}$ to heavy-section ductile-iron castings exhibited a beneficial effect of a decreasing $\mathrm{CHG}$ area as reported in other works. ${ }^{5,13,14}$

\section{CONCLUSION}

Based on the results obtained in this study, the following main conclusions can be drawn:

- CHG occurred in the thermal center of a heavysection ductile-iron casting;

- a $\mathrm{Bi}$ addition has a positive influence on the $\mathrm{CHG}$ suppression in thick-section areas, while maintaining good mechanical properties in thin-section areas;

- the Bi addition also improved the tensile strength and elongation in the $\mathrm{CHG}$ area;

- for the investigated section size, the addition of $\mathrm{Bi}$ was too low to totally suppress the CHG formation.

\section{Acknowledgements}

This work was partially supported by the foundry MIV d.d., Varaždin.

\section{REFERENCES}

${ }^{1}$ H. Löblich, Effect of nucleation conditions on the development of chunky graphite in heavy ductile iron castings, Giessereiforschung, 58 (2006) 3, 28-41

${ }^{2}$ O. Knustad, L. Magnusson Åberg, Chunky graphite, effects and theories on formation and prevention, $14^{\text {th }}$ Inter. Foundry Conference, Opatija, Croatia, 2014

${ }^{3}$ R. Källbom, K. Hamberg, M. Wessen, L.-E. Björkegren, On the solidification sequence of ductile iron castings containing chunky graphite, Materials Science and Engineering A, 413-414 (2005), 346-351, doi:10.1016/j.msea.2005.08.210

${ }^{4}$ J. Lacaze, L. Magnusson, J. Sertucha, Review of microstructural features of chunky graphite in ductile cast irons, Keith Millis Symp. on Ductile Cast Iron, Nashville, USA, 2013, 360-368

${ }^{5}$ P. Ferro, A. Fabrizi, R. Cervo, C. Carollo, Effect of inoculant containing rare earth metals and bismuth on microstructure and mechanical properties of heavy-section near-eutectic ductile iron castings, Journal of Materials Processing Technology, 213 (2013), 1601-1608, doi:10.1016/j.jmatprotec.2013.03.012 


\section{MATERIALI IN TEHNOLOGIJE/MATERIALS AND TECHNOLOGY (1967-2017) - 50 LET/50 YEARS}

\section{MIHALIC POKOPEC et al.: EFFECT OF INOCULATION ON THE FORMATION OF CHUNKY GRAPHITE ...}

${ }^{6}$ K. Hartung, O. Knustad, K. Wardenaer, Chunky graphite in ductile cast iron castings - Theories and examples, Indian Foundry Journal, 55 (2009), 25-29

${ }^{7}$ R. Källbom, K. Hamberg, L. E. Björkegren, Chunky Graphite Formation and Influence on Mechanical Properties in Ductile Cast Iron, Proc. of Gjutdesign 2005, Espoo, Finland, 2005

${ }^{8}$ S. Mendez, D. Loper, I. Asenjo, P. Larrañaga, J. Lacaze, Improved analytical method for chemical analysis of cast iron, Application to castings with chunky graphite, ISIJ International, 51 (2011), 242-249

${ }^{9}$ P. C. Liu, C. R. Loper Jr., T. Kimura, H. K. Park, Study of chunky graphite in heavy section ductile iron, AFS Transactions, 83-51 (1983), 119-126

${ }^{10}$ E. N. Pan, C. Y. Chen, Effects of $\mathrm{Pb}$ and solidification conditions on the graphite structure of heavy-section ductile cast iron, AFS Transactions, 103 (1995), 265-273
${ }^{11}$ M. Koch, Chunky Graphite, Effects and theories on formation and prevention, 2013 Keith Millis Symp. on Ductile Cast Iron, Nashville, USA, 2013

${ }^{12}$ P. Larrañaga, I. Asenjo, J. Sertucha, R. Suarez, I. Ferrer, J. Lacaze, Effect of Antimony and Cerium on the Formation of Chunky Graphite during Solidification of Heavy-Section Castings, Metallurgical and Materials Transactions A, 36A (2009), 654-661, doi:10.1007/ s11661-008-9731-y

${ }^{13}$ E. N. Pan, C. Y. Chen, Effects of Bi and Sb on graphite structure of heavy-section ductile cast iron, AFS Transactions, 104 (1996), $845-858$

${ }^{14}$ J. Riposan, M. Chisamera, S. Stan, Performance of heavy ductile iron castings for windmills, China Foundry, 7 (2010) 2, 163-170 